\title{
Dissolved Black Carbon and Semivolatile Aromatic Hydrocarbons in the Ocean: Two Entangled Biogeochemical Cycles?
}

\author{
Núria Trilla-Prieto, Maria Vila-Costa, Gemma Casas, Begoña Jiménez, and Jordi Dachs*
}

Cite This: Environ. Sci. Technol. Lett. 2021, 8, 918-923

Read Online

ABSTRACT: Dissolved black carbon (DBC) plays a role in the oceanic carbon cycle. DBC originates from the heating and incomplete combustion of organic matter, including fossil fuels, a shared origin with polycyclic aromatic hydrocarbons $(\mathrm{PAH}) . \mathrm{DBC}$ is quantified using the benzene polycarboxylic acids produced by oxidation of the organic extract, a fraction of which derive from PAHs and other semivolatile aromatic-like compounds (SALCs). However, the current view of the DBC cycle does not take into account the inputs and sinks known for PAHs, such as diffusive air-water exchange and degradation. A meta-analysis of oceanic PAHs, SALCs, and DBC concentrations shows that SALCs account for $16 \%$ of DBC (ranging from $5 \%$ to $31 \%$ ). Such a large contribution of semivolatile aromatic hydrocarbons to DBC is consistent with the large atmospheric input of SALCs (estimated as $400 \mathrm{Tg} \mathrm{C}^{-1}$ ). Furthermore, photodegradation at the surface ocean and microbial degradation in the water column of semivolatile DBC can be

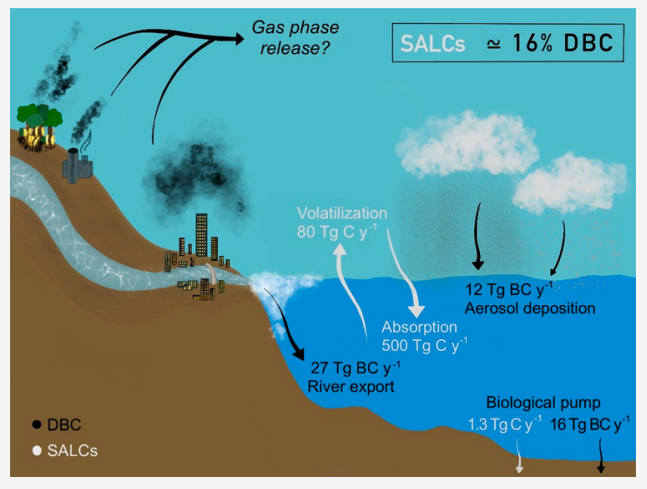
important sinks, consistent with the ubiquitous occurrence of the degradation genes of the metabolic routes for aromatic hydrocarbons. Future work should focus on the characterization of semivolatile DBC and its degradation in order to constrain its contribution to refractory organic matter and the anthropogenic perturbation of the carbon cycle.

\section{INTRODUCTION}

Black carbon originates from the heating and combustion of organic matter, such as during forest fires or use of fossil fuels. Semivolatile polycyclic aromatic hydrocarbons (PAHs) are also produced during these combustion processes, even though PAHs can also be released to the environment due to oil spills or even from natural sources. Particulate black carbon has been extensively studied in soils and the atmosphere due to its role in Earth radiation balance, health effects, and as an environmental sorbent for PAHs and other pollutants. ${ }^{1-3}$ During recent years, there has been an increasing interest in dissolved black carbon (DBC) in the ocean. ${ }^{3}$ Oceanic DBC accounts for between $0.1 \%$ and $4-7 \%$ of dissolved organic carbon (DOC). ${ }^{3}$ $\mathrm{DBC}$ is old carbon, as determined by $\Delta^{14} \mathrm{C}$ isotopic determinations, ${ }^{4,5}$ and it has been suggested that DBC contributes to refractory organic matter and plays a key role in the slow cycle of DOC in the ocean. ${ }^{5}$ Even though the major identified sources of DBC are riverine inputs, followed by atmospheric deposition of aerosol-bound black carbon, ${ }^{3,6}$ the $\delta^{13} \mathrm{C}$ signal of oceanic $\mathrm{DBC}$ is different than that of rivers, suggesting unaccounted sources of oceanic DBC. ${ }^{7}$

$\mathrm{DBC}$ is generally quantified by using benzene polycarboxylic acids (BPCA) as a proxy, and the determination of BPCA has become an operational definition of $\mathrm{DBC}$, as the condensed aromatic fraction of DOC. BPCA are produced during the oxidation of pyrogenic organic matter ${ }^{8,9}$ from well-known PAHs such as phenanthrene, pyrene, or benzo[a]pyrene but also from complex aromatic molecules present within the DBC pool of organic matter. Even though PAHs are known to be oxidized to BPCA, the accumulated knowledge of the biogeochemical cycle of PAHs and other semivolatile aromatic-like compounds (SALCs) $)^{10,11}$ has been largely omitted when deciphering the transport, biogeochemical cycling, and fate of $\mathrm{DBC}^{3}$ While rivers and aerosol-bound PAHs are a known source of SALCs to the ocean, diffusive air-water exchange accounts for most of the input of SALCs, including PAHs and a large aromatic unresolved complex mixture (UCM), to the open ocean. ${ }^{10}$ The relative importance of the different atmospheric inputs of aromatic compounds depend on their gas-particle partitioning, which is proportional to molecular weight and volatility. High MW PAHs are mainly deposited bound to aerosols, while PAHs with 2-5 aromatic rings are mainly deposited through diffusive exchange. ${ }^{10}$ Concerning the oceanic sinks of PAHs, direct photolysis is important in the surface ocean, ${ }^{11}$ but microbial degradation is the main sink in the overall water column. ${ }^{11}$ The relevance of

Received: August 14, 2021

Published: September 9, 2021 

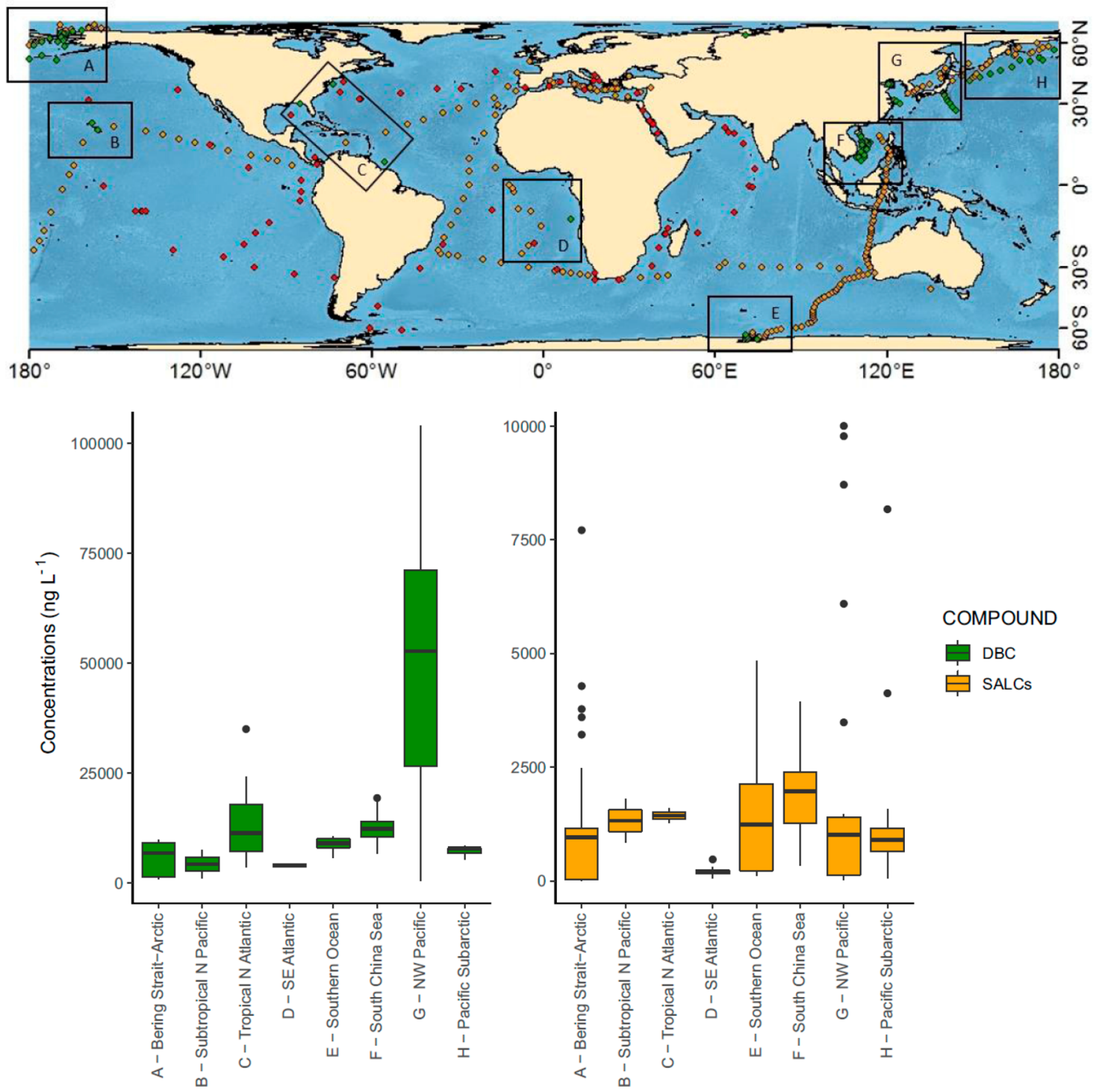

Figure 1. Comparison of dissolved black carbon and semivolatile aromatic-like hydrocarbons (SALCs) in the ocean. Upper panel shows all data points collected in the compilation. Green dots mark all DBC measurements, orange dots all PAHs measurements, and red dots all gene data points from Tara Oceans. Lower panel shows the box-plots of the dissolved black carbon and dissolved aromatic hydrocarbons for the eight oceanic regions shown in the upper panel.

biodegradation of DBC in the ocean is unclear. While charcoal leachates can partly be photo- and biodegraded, ${ }^{12}$ as these contain a large suite of organic chemicals and not only condensed aromatic organic matter, its relevance for the persistence of oceanic DBC is under debate. ${ }^{13,14}$

The objective of this work was to compare the marine occurrence of SALCs and DBC, assess how the known biogeochemical cycle of PAHs can shed light to the sources and fate of oceanic DBC by addressing the feasibility of DBC photo- and biodegradation, the latter derived from oceanic metagenomes, and the implications of semivolatile DBC for this important pool of refractory DOC.

\section{MATERIALS AND METHODS}

Meta-Analysis of DBC and PAH Concentrations. The meta-analysis of DBC and PAH concentrations considered those papers reporting the dissolved phase concentrations of $\mathrm{BC}$ and PAHs. DBC and PAH literature sources were limited to those reporting concentrations in surface waters $(0-25 \mathrm{~m}$ for the $\mathrm{DBC}$ and $0-10 \mathrm{~m}$ for PAHs) from the open ocean and coastal regions. ${ }^{4,5,7-30}$ Reports of DBC and PAHs in rivers and estuaries were not considered. Generally, there are more oceanic measurements for PAHs than for DBC. However, all the DBC reports used the BPCA approach, with similar sampling and analysis methods, while PAHs sampling and the number of targeted compounds differ between studies. In this work, we take the operational definition of DBC as derived from the use of BPCA as a proxy, which defines DBC as the fraction of DOC with condensed aromatics. Validation of the DBC extraction methods and BPCA determination has demonstrated that not only high MW aromatic chemicals are quantified as DBC but also PAHs with a number of aromatic rings ranging from 3 to $7 .^{8,9}$ For example, the BPCA method has been validated for phenanthrene, pyrene, and fluoranthenes, ${ }^{9}$ which are semivolatile PAHs with important diffusive inputs to the ocean. ${ }^{10}$

The different number of targeted PAHs in the different reports of marine PAHs needs to be taken into account when 

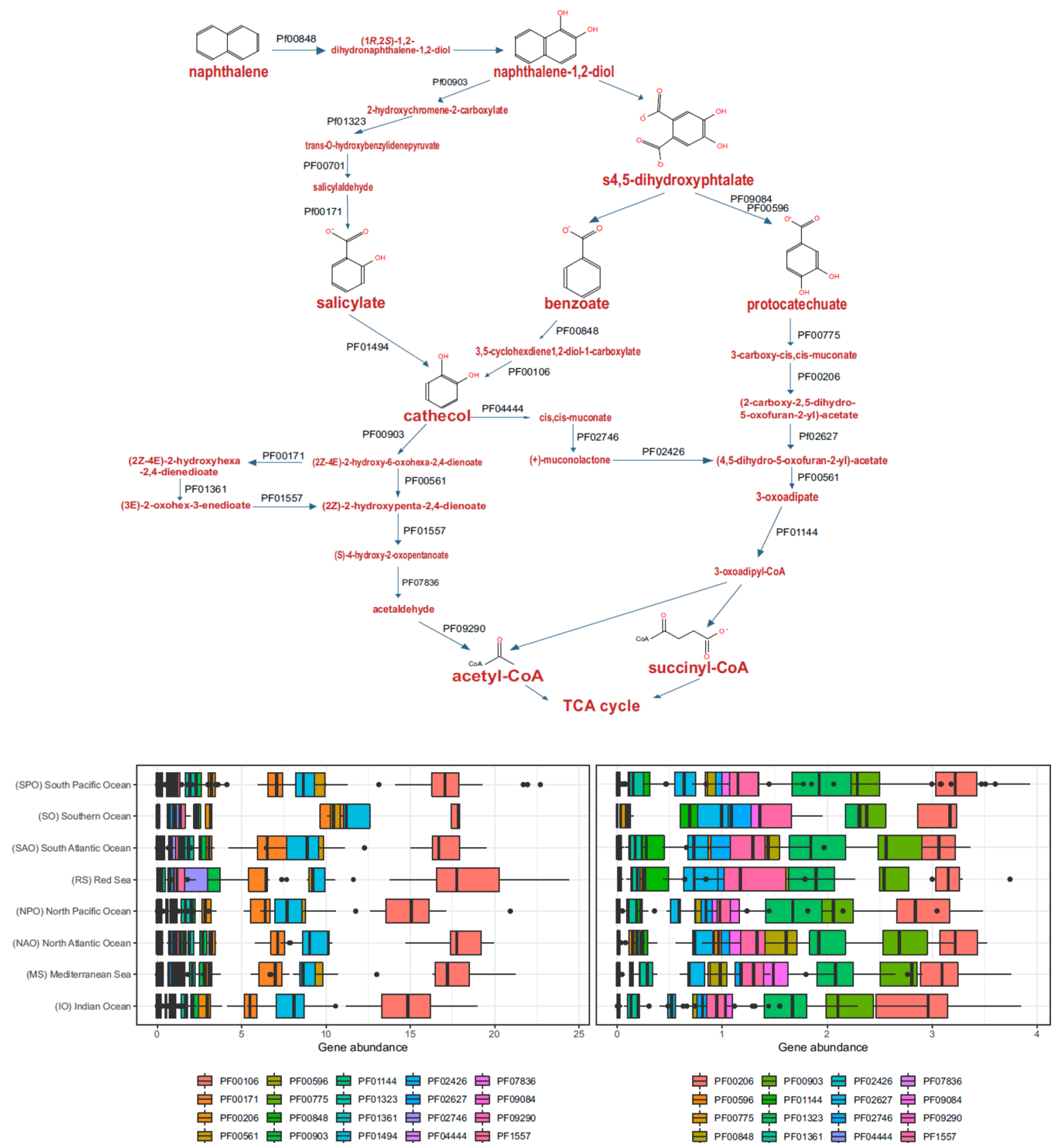

Figure 2. Abundance of key genes, from the Tara Oceans metagenomes, responsible for the metabolic routes of the degradation of aromatic hydrocarbons. Upper panel shows the PAH degradation route, and the lower panel the single-copy normalized abundance of the genes (notice the lower panel on the right zooms the less abundant genes). From the most abundant genes to the lowest, mean surface concentrations (copies/cell) are PF00106 at 16.7, PF00561 at 9.06, PF01494 at 8.89, PF00171 at 6.71, PF00206 at 3.13, PF00903 at 2.44, PF01323 at 1.94, PF09084 at 1.81, PF1557 at 1.69, PF02746 at 1.03, PF00848 at 1.01, PF00596 at 0.928, PF02627 at 0.650, PF01144 at 0.276, PF01361 at 0.190, PF00775 at 0.131, PF07836 at 0.0199 , PF09290 at 0.0192, PF02426 at 0.0145 , and PF0444 at 0.0628 .

estimating the total SALCs. Phenanthrene, anthracene, fluoranthene, and pyrene were taken as the reference compounds for comparing the different works reporting PAHs (as $\sum_{4} \mathrm{PAH}$ ), as the concentrations for these individual hydrocarbons are commonly reported in all previous field assessments of PAHs. Other works report up to 64 individual PAHs. ${ }^{10,11,27}$ For the SALCs estimation, we used a mean ratio for the $\sum_{64} \mathrm{PAH} / \sum_{4} \mathrm{PAH}$ of 2.46 and a mean ratio SALCs/ $\sum_{64} \mathrm{PAH}$ of 456 as reported elsewhere. ${ }^{9,10,24}$ This approach allowed us to undertake a conversion of the PAH concentrations to the total SALCs, so the comparison of SALCs and DBC could be done. The data set compiled did not include the values under the detection limit. Only DBC and $\mathrm{PAH}$ concentrations determined from active solid phase extraction of seawater were considered.

From all the compiled data, eight specific zones were selected where data from DBC and PAHs were available (Figure 1). Mean and SD were calculated for each zone and chemical class. In order to assess the contribution from SALCs to $\mathrm{DBC}$, the ratios of SALCs/DBC were calculated for each zone (Table S1).

Bioinformatics. Relative abundances of PAH-degrading genes were quantified using hidden Markov models (HMMs) which are sensitive tools for the identification of protein and 
protein domain sequences. HMMs corresponding to the complete degradation of naphthalene (as model PAH molecule, Figure 2) were downloaded from the Pfam website. ${ }^{31}$ Similarly, HMMs corresponding to five single-copy marker genes were also downloaded (namely, PF00154, PF00204, PF04561, PF04563, and PF04565). The HMMs were used to search all protein sequences from metagenomes from the Tara Oceans expedition (2009-2013) (2) $^{2}$ using HMMER $^{33}$ with score thresholds built into the Pfam profiles. The identified proteins were subsequently quantified in surface and deep-chlorophyll maximum (DCM) samples of the freeliving bacterial fraction (cells collected on an $0.22 \mu \mathrm{m}$ filter after prefiltration through a $3 \mu \mathrm{m}$ filter). The $\mathrm{PAH}$-degrading gene abundances were normalized by division with the mean abundance of the five single-copy genes.

\section{RESULTS AND DISCUSSION}

Our meta-analysis of reported concentrations of DBC shows that most previous measurements have so far covered continental shelf regions in the western and northern Pacific Ocean regions, in the eastern North Atlantic, and some measurements in the maritime Antarctica (Figure 1). There are large open ocean regions that remain unassessed in terms of DBC occurrence and cycling. Concentrations of oceanic DBC range between 0.0005 and $0.104 \mathrm{mg} \mathrm{C} \mathrm{L}^{-1}$, with the highest concentrations in the Northwest Pacific (regional average of $0.048 \mathrm{mg} \mathrm{C} \mathrm{L}^{-1}$ ). This is consistent with the available data of global carbon emissions, as China, with a gross population of 1.36 billion in East Asia, is the world's largest BC emitter. ${ }^{34}$ In the Southern Ocean and maritime Antarctica, the values ranged between 0.005 and $0.01 \mathrm{mg} \mathrm{C} \mathrm{L}^{-1}$, while in the Arctic region $\mathrm{DBC}$ ranged between 0.0009 and $0.009 \mathrm{mg} \mathrm{C} \mathrm{L}^{-1}$ in the Bering Sea and between 0.005 and $0.008 \mathrm{mg} \mathrm{C} \mathrm{L}^{-1}$ in the Subarctic North Pacific. No other latitudinal trends were found a part from the lower values found in the Arctic and Antarctica.

Previous PAH measurements show a more complete spatial coverage of the vast oceanic regions thanks to measures performed during north-south latitudinal transects in the eastern Atlantic and western Pacific, in polar regions, and during the Malaspina circumnavigation. Depending on the research group performing the analysis, a different number of targeted PAHs are considered. In this work, we took the sum of phenanthrene, anthracene, pyrene, and fluoranthene as reference for comparison purposes, as these four PAHs are commonly targeted in all studies. The $\sum_{4} \mathrm{PAH}$ ranged from 0.003 to $11.3 \mathrm{ng} \mathrm{L}^{-1}$, with a mean of $1.34 \mathrm{ng} \mathrm{L}^{-1}$. Concentrations of PAHs in the Southern Ocean and maritime Antarctica ranged from 0.011 to $4.3 \mathrm{ng} \mathrm{L}^{-1}$ and in the Arctic from 0.4 to $6.8 \mathrm{ng} \mathrm{L} \mathrm{L}^{-1}$. The number of individual PAHs reported in the literature usually range between 16 and $64,{ }^{10,27}$ as determined by target analysis, but these account for a small fraction of the total SALCs in natural waters. The estimated SALCs in the ocean, including PAHs and the aromatic UCM (see Materials and Methods), average $2500 \mathrm{ng} \mathrm{L}^{-1}$, ranging between 350 and $4500 \mathrm{ng} \mathrm{L}{ }^{-1}{ }^{10}$

The comparison of DBC and SALC concentrations was feasible for eight oceanic regions (Figure 1 and Figure S1). For these regions, SALCs account for $16 \%$ of reported DBC concentrations, ranging between $5 \%$ and $31 \%$ of DBC (Table S1). The ratio of SALCs/DBC shows a remarkable variability (Table S1). The lowest SALCs/DBC ratios were found in the Atlantic (Zones C and D in Figure 1), especially in the South Atlantic Ocean (SALCs $/ \mathrm{DBC}=5$, zone D), which receives inputs of DBC from Africa and South America (probably important sources from forest fires). The ratios in the Northwest Pacific (SALCs/DBC $=4.6$, zone G) are also low, comparable to those in the South Atlantic. The sources of atmospheric particulate black carbon are enormous in eastern Asia (China and India among other countries), which suggest that sources of DBC through rivers and/or the atmosphere may also be important, thus resulting in a lower SALCs/DBC ratio. This would mean that those oceanic regions receiving higher inputs of DBC from biomass (maybe anthropogenic as well) may have lower SALCs/DBC ratios. On the contrary, in the Arctic and Subarctic (Zones A, B, and H), the ratios of SALCs/DBC were the highest (ranging from 22 to 31 ), which suggest that these regions have higher input of PAHs and other semivolatile aromatic compounds. The ratio in other remote regions such as in the Southern Ocean is also high (15.7, zone E) but lower than in the Arctic. In any case, the Southern Ocean is the most distant region to known sources of both DBC and PAHs.

A number of PAHs with 3-7 aromatic rings have been used to validate the BPCA analytical methods commonly used to quantify DBC. 8 As DBC can be viewed as the condensed aromatic fraction of DOC, this comparison shows that there is a significant and relevant fraction of DBC that is composed of semivolatile aromatic compounds. This contrasts with the current view of the DBC cycle in the ocean, ${ }^{3}$ which neglects those processes and sources known to be important for semivolatile aromatic compounds. Semivolatile DBC exchanges diffusively between the atmosphere and the ocean. Rivers have been thought, so far, to be the main input of $\mathrm{DBC}$, estimated as $27 \mathrm{Tg} \mathrm{C} \mathrm{y}^{-13}$, followed by partial dissolution of aerosol black carbon in seawater, as DBC after atmospheric deposition, estimated as an input of $1.8 \mathrm{Tg} \mathrm{C}^{-13}$. In comparison, the atmospheric deposition of aerosol BC is of 12 $\mathrm{TgC} \mathrm{y}^{-11}$. The estimated atmospheric deposition input of aerosol-bound SALCs to the ocean is of $6 \mathrm{Tg} \mathrm{C}^{-1}$, thus about $50 \%$ the deposition of aerosol BC. Part of these SALCs, together with yet unquantified oxidized SALCs present in aerosols, account for the observed water-soluble BC fraction (or DBC). However, most of PAHs and SALCs enter the ocean by diffusive air-water exchange, ${ }^{9}$ which has been estimated as an input of $400 \mathrm{Tg} \mathrm{C} \mathrm{y}{ }^{-1}$, much larger than previously reported inputs of $\mathrm{DBC}$. This suggests that in the open ocean, atmospheric deposition, rather than rivers, will be the main input of DBC. Furthermore, diffusive air-water exchange accounts for a direct input to the dissolved phase, without the redissolution and partitioning processes between deposited aerosols and water.

An important issue is to discern to which degree this large input of semivolatile DBC is consistent with our current knowledge of the DBC cycle in the ocean. The $\delta^{13} \mathrm{C}$ signal of oceanic $\mathrm{DBC}$ is enriched when compared with rivers. A large input by diffusive air-water exchange could account for a fraction of the missing source of DBC in the ocean as indicated by the $\delta^{13} \mathrm{C}$ signal of oceanic DBC. Unfortunately, the $\delta^{13} \mathrm{C}$ signal of gas phase SALCs remains unknown. However, the few available $\delta^{13} \mathrm{C}$ measurements for PAHs in soils have been reported to range between $-23.81 \%$ and $-24.19 \% .^{35}$ The potential importance of an anthropogenic source of DBC in the ocean is also consistent with $\delta^{13} \mathrm{C}$ of $-23.2 \%$ for coal pyrolysis at low temperature and $-25.3 \%$ for liquid fuel combustion. ${ }^{35}$ The $\Delta^{14} \mathrm{C}$ of BPCA in the ocean shows old carbon, ${ }^{3}$ which would also be consistent with a relevant 
contribution from anthropogenic SALCs. Future work should resolve the isotopic signal of semivolatile DBC inputs. Second, the assessment of oceanic sinks can provide further evidence of the key controls of oceanic DBC. The biological pump fluxes of DBC and SALCs, referred here as settling to deep waters due to DBC and SALC partitioning to sinking particles, have been estimated to be 16 and $1.3 \mathrm{Tg} \mathrm{C} \mathrm{y}^{-1}$, respectively. ${ }^{3,10}$ These figures are much lower than the atmospheric inputs of aromatic compounds; therefore, there are large sinks that account for more than $96 \%$ and $99 \%$ of the DBC and SALCs removal in the photic zone, respectively. For SALCs, photoand biodegradation can account for this large degradation of SALCs. Direct photodegradation of PAHs is important in the surface ocean, while biodegradation has been suggested to dominate in the top $200 \mathrm{~m}$ of the ocean. ${ }^{11}$ Photodegradation has also been reported to be relevant as a transformation mechanism of DOC in the top ocean ${ }^{36}$ and could be analogously relevant for DBC. Experiments done by irradiating deep oceanic waters showed that a fraction of DBC can be photodegraded, suggesting that this is limited by the short time period that DBC molecules spend in the surface ocean. ${ }^{18}$ The microbial degradation routes of aromatic compounds in seawater are fairly well known, ${ }^{37,38}$ and the first step in this degradation is performed by ring hydroxylating dioxygenase, widespread in the surface ocean. ${ }^{11}$ While hydroxylated PAHs are not quantified by target analysis of PAHs, they would still be quantified as DBC using BPCA as a proxy. A more complete degradation of aromatic compounds is needed in order to quantify the removal of DBC from the water column. Analysis of oceanic metagenomes show that there is widespread occurrence of the genes involved in the metabolic routes of aromatic compounds in oceanic microbiomes (Figure 2). As far as we know, this is the first time that the ubiquity of the genes responsible for complete degradation of aromatic hydrocarbons are assessed in the ocean. Such ubiquity of degradation genes suggests that this degradation of DBC is feasible, even though the fact that some genes have very low abundance (Figure 2) may limit the degree of respiration of DBC. However, large aromatic compounds show slower biodegradation than smaller aromatic molecules and independent of their oxidation degree will partition to particulate organic matter (including soot), which may significantly decrease the bioavailable fraction of DBC for microbial degradation. Therefore, there is the possibility of a contrasting fate of two DBC pools. On one side are the semivolatile DBC pool (SALCs), with lower MW aromatic molecules which are largely degraded in the ocean, and on the other side are the high MW condensed aromatic compounds, also being part of DBC which may be recalcitrant in the marine environment. These biogeochemical controls on the fate of DBC degradation will require further experimental confirmation in the future. Current field evidence shows, however, that $\mathrm{BC} / \mathrm{OC}$ in sediments can be as high as $0.35,{ }^{2}$, while in the surface ocean, the $\mathrm{DBC} / \mathrm{DOC}$ range is between 0.001 and $0.07 .^{3}$ As part of the biogeochemical cycle of $\mathrm{DBC}$, there is a continuous partitioning between the dissolved and particulate phases (also for the transformation products), as known for PAHs. Thus, the oceanic cycles of dissolved and particulate $\mathrm{BC}$ are closely coupled. Despite an important degradation of DBC in surface waters, mainly the semivolatile component (SALCs), there is a preferential degradation of organic matter in comparison to $\mathrm{BC}$, thus rendering $\mathrm{DBC}$ and particulate black carbon key components of the refractory carbon in the ocean. The consideration of a semivolatile component of the black carbon cycle, previously neglected, has important implications for the understanding of the marine cycle of this ultimately recalcitrant pool of organic matter and its anthropogenic perturbation.

\section{ASSOCIATED CONTENT}

\section{Supporting Information}

The Supporting Information is available free of charge at https://pubs.acs.org/doi/10.1021/acs.estlett.1c00658.

Summary of DBC and PAH concentrations (Table S1) and global distribution of DBC and SALC concentrations (Figure S1) (PDF)

\section{AUTHOR INFORMATION}

\section{Corresponding Author}

Jordi Dachs - Department of Environmental Chemistry, IDAEA-CSIC, Barcelona, Catalunya 08034, Spain; ○ orcid.org/0000-0002-4237-169X; Email: jordi.dachs@ idaea.csic.es

\section{Authors}

Núria Trilla-Prieto - Department of Environmental Chemistry, IDAEA-CSIC, Barcelona, Catalunya 08034, Spain; orcid.org/0000-0001-6973-9514

Maria Vila-Costa - Department of Environmental Chemistry, IDAEA-CSIC, Barcelona, Catalunya 08034, Spain

Gemma Casas - Department of Environmental Chemistry, IDAEA-CSIC, Barcelona, Catalunya 08034, Spain

Begoña Jiménez - Department of Instrumental Analysis and Environmental Chemistry, IQOG-CSIC, Madrid 28006,

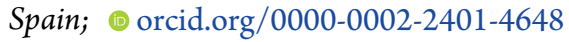

Complete contact information is available at: https://pubs.acs.org/10.1021/acs.estlett.1c00658

\section{Notes}

The authors declare no competing financial interest.

\section{ACKNOWLEDGMENTS}

This work was supported by the ANTOM project funded by the Spanish Research Agency from the Ministry of Science (PGC2018-096612-B-I00). N.T. and G.C. acknowledge FPI Ph.D. fellowships from the Spanish Research Agency. The research group of Global Change and Genomic Biogeochemistry receives support from the Catalan Government (2017SGR800). This research is part of POLARCSIC activities. IDAEA-CSIC is a Centre of Excellence Severo Ochoa (Spanish Ministry of Science and Innovation, Project CEX2018-000794-S).

\section{REFERENCES}

(1) Jurado, E.; Dachs, J.; Duarte, C. M.; Simó, R. Atmospheric deposition of organic and black carbon to the global oceans. Atmos. Environ. 2008, 42, 7931-7939.

(2) Lohmann, R.; Bollinger, K.; Cantwell, M.; Feichter, J.; FischerBruns, I.; Zabel, M. Fluxes of soot black carbon to South Atlantic sediments. Global Biogeochem. Cycles 2009, 23, GB1015.

(3) Wagner, S.; Jaffé, R.; Stubbins, A. Dissolved black carbon in aquatic ecosystems. Limnol. Oceanogr. Lett. 2018, 3, 168-185.

(4) Ziolkowski, L. A.; Druffel, E. R. M. Aged black carbon identified in marine dissolved organic carbon. Geophys. Res. Lett. 2010, 37, 4-7.

(5) Coppola, A. I.; Druffel, E. R. M. Cycling of black carbon in the ocean. Geophys. Res. Lett. 2016, 43, 4477-4482. 
(6) Bao, H.; Niggemann, J.; Luo, L.; Dittmar, T.; Kao, S. J. Aerosols as a source of dissolved black carbon to the ocean. Nat. Commun. 2017, 8, 8 .

(7) Wagner, S.; Brandes, J.; Spencer, R. G. M.; Ma, K.; Rosengard, S. Z.; Moura, J. M. S.; Stubbins, A. Isotopic composition of oceanic dissolved black carbon reveals non-riverine source. Nat. Commun. 2019, 10, 1-8.

(8) Dittmar, T. The molecular level determination of black carbon in marine dissolved organic matter. Org. Geochem. 2008, 39, 396-407.

(9) Ziolkowski, L. A.; Chamberlin, A. R.; Greaves, J.; Druffel, E. R. M. Quantification of black carbon in marine systems using the benzene polycarboxylic acid method: a mechanistic and yield study. Limnol. Oceanogr.: Methods 2011, 9, 140-149.

(10) González-Gaya, B.; Fernández-Pinos, M.-C.; Morales, L.; Méjanelle, L.; Abad, E.; Piña, B.; Duarte, C. M.; Jiménez, B.; Dachs, J. High atmosphere-ocean exchange of semivolatile aromatic hydrocarbons. Nat. Geosci. 2016, 9, 438-442.

(11) González-Gaya, B.; Martínez-Varela, A.; Vila-Costa, M.; Casal, P.; Cerro-Gálvez, E.; Berrojalbiz, N.; Lundin, D.; Vidal, M.; Mompeán, C.; Bode, A.; Jiménez, B.; Dachs, J. Biodegradation as an important sink of aromatic hydrocarbons in the oceans. Nat. Geosci. 2019, 12, 119-125.

(12) Qi, Y.; Fu, W.; Tian, J.; Luo, C.; Shan, S.; Sun, S.; Ren, P.; Zhang, H.; Liu, J.; Zhang, X.; Wang, X. Dissolved Black Carbon Is Not Likely a Significant Refractory Organic Carbon Pool in Rivers and Oceans. Nat. Commun. 2020, 11, 5051.

(13) Bostick, K. W.; Zimmerman, A. R.; Goranov, A. I.; Mitra, S.; Hatcher, P. G.; Wozniak, A. S. Biolability of fresh and photodegraded pyrogenic dissolved organic matter from laboratory-prepared chars. J. Geophys. Res.: Biogeosci. 2021, 126, e2020JG005981.

(14) Wagner, S.; Coppola, A. I.; Stubbins, A.; Dittmar, T.; Niggemann, J.; Drake, T. W.; Seidel, M.; Spencer, R. G. M.; Bao, $\mathrm{H}$. Questions remain about the biolability of dissolved black carbon along the combustion continuum. Nat. Commun. 2021, 12, 4281.

(15) Fang, Y.; Chen, Y.; Tian, C.; Wang, X.; Lin, T.; Hu, L.; Li, J.; Zhang, G.; Luo, Y. Cycling and Budgets of Organic and Black Carbon in Coastal Bohai Sea, China: Impacts of Natural and Anthropogenic Perturbations. Global Biogeochem. Cycles 2018, 32, 971-986.

(16) Fang, Z.; Yang, W.; Chen, M.; Ma, H. Source and Fate of Dissolved Black Carbon in the Western South China Sea During the Southwest Monsoon Prevailing Season. J. Geophys. Res. J. Geophys. Res.: Biogeosci. 2017, 122, 2817-2830.

(17) Fang, Z.; Yang, W.; Chen, M.; Stubbins, A.; Ma, H.; Jia, R.; Li, Q.; Chen, Q. Transport of Dissolved Black Carbon from the Prydz Bay Shelf, Antarctica to the Deep Southern Ocean. Limnol. Oceanogr. 2018, 63, 2179-2190.

(18) Stubbins, A.; Niggemann, J.; Dittmar, T. Photo-Lability of Deep Ocean Dissolved Black Carbon. Biogeosciences 2012, 9, 16611670.

(19) Nakane, M.; Ajioka, T.; Yamashita, Y. Distribution and Sources of Dissolved Black Carbon in Surface Waters of the Chukchi Sea, Bering Sea, and the North Pacific Ocean. Front. Earth Sci. 2017, 5, 112.

(20) Dittmar, T.; Paeng, J.; Gihring, T. M.; Suryaputra, I. G. N. A.; Huettel, M. Discharge of Dissolved Black Carbon from a Fire-Affected Intertidal System. Limnol. Oceanogr. 2012, 57 (4), 1171-1181.

(21) Dittmar, T.; De Rezende, C. E.; Manecki, M.; Niggemann, J.; Coelho Ovalle, A. R.; Stubbins, A.; Bernardes, M. C. Continuous Flux of Dissolved Black Carbon from a Vanished Tropical Forest Biome. Nat. Geosci. 2012, 5 (9), 618-622.

(22) Mannino, A.; Harvey, H. R. Black Carbon in Estuarine and Coastal Ocean Dissolved Organic Matter. Limnol. Oceanogr. 2004, 49 (3), 735-740.

(23) Dittmar, T.; Paeng, J. A Heat-Induced Molecular Signature in Marine Dissolved Organic Matter. Nat. Geosci. 2009, 2 (3), 175-179.

(24) Ke, H.; Chen, M.; Liu, M.; Chen, M.; Duan, M.; Huang, P.; Hong, J.; Lin, Y.; Cheng, S.; Wang, X.; Huang, M.; Cai, M. Fate of Polycyclic Aromatic Hydrocarbons from the North Pacific to the
Arctic: Field Measurements and Fugacity Model Simulation. Chemosphere 2017, 184, 916-923.

(25) Ma, Y.; Xie, Z.; Yang, H.; Möller, A.; Halsall, C.; Cai, M.; Sturm, R.; Ebinghaus, R. Deposition of Polycyclic Aromatic Hydrocarbons in the North Pacific and the Arctic. J. Geophys. Res. Atmos. 2013, 118 (11), 5822-5829.

(26) Zheng, H.; Cai, M.; Zhao, W.; Khairy, M.; Chen, M.; Deng, H.; Lohmann, R. Net Volatilization of PAHs from the North Pacific to the Arctic Ocean Observed by Passive Sampling. Environ. Pollut. 2021, 276, 116728.

(27) Casal, P.; Cabrerizo, A.; Vila-Costa, M.; Pizarro, M.; Jiménez, B.; Dachs, J. Pivotal Role of Snow Deposition and Melting Driving Fluxes of Polycyclic Aromatic Hydrocarbons at Coastal Livingston Island (Antarctica). Environ. Sci. Technol. 2018, 52, 12327-12337.

(28) Casal, P.; Casas, G.; Vila-Costa, M.; Cabrerizo, A.; Pizarro, M.; Jiménez, B.; Dachs, J. Snow Amplification of Persistent Organic Pollutants at Coastal Antarctica. Environ. Sci. Technol. 2019, 53 (15), $8872-8882$

(29) Nizzetto, L.; Lohmann, R.; Gioia, R.; Jahnke, A.; Temme, C.; Dachs, J.; Herckes, P.; Di Guardo, A.; Jones, K. C. PAHs in Air and Seawater along a North-South Atlantic Transect: Trends, Processes and Possible Sources. Environ. Sci. Technol. 2008, 42 (5), 1580-1585.

(30) Berrojalbiz, N.; Dachs, J.; Ojeda, M. J.; Valle, M. C.; CastroJiménez, J.; Wollgast, J.; Ghiani, M.; Hanke, G.; Zaldivar, J. M. Biogeochemical and Physical Controls on Concentrations of Polycyclic Aromatic Hydrocarbons in Water and Plankton of the Mediterranean and Black Seas. Global Biogeochem. Cycles 2011, 25 (4), $1-14$.

(31) Finn, R. D.; Coggill, P.; Eberhardt, R. Y.; Eddy, S. R.; Mistry, J.; Mitchell, A. L.; Potter, S. C.; Punta, M.; Qureshi, M.; SangradorVegas, A.; Salazar, G. A.; Tate, J.; Bateman, A. The Pfam protein families database: towards a more sustainable future. Nucleic Acids Res. 2016, 44, D279-D285.

(32) Pesant, S.; Not, F.; Picheral, M.; Kandels-Lewis, S.; Le Bescot, N.; Gorsky, G.; Iudicone, D.; Karsenti, E.; Speich, S.; Trouble, R.; Dimier, C.; Searson, S. Open science resources for the discovery and analysis of Tara Oceans data. Sci. Data 2015, 2, 150023.

(33) Eddy, S. R. Accelerated profile HMM searches. PLoS Comput. Biol. 2011, 7, e1002195.

(34) Wang, R.; Tao, S.; Wang, W.; Liu, J.; Shen, H.; Shen, G.; Wang, B.; Liu, X.; Li, W.; Huang, Y.; Zhang, Y.; Lu, Y.; Chen, H.; Chen, Y.; Wang, C.; Zhu, D.; Wang, X.; Li, B.; Liu, W.; Ma, J. Black carbon emissions in China from 1949 to 2050. Environ. Sci. Technol. 2012, 46, $7595-7603$

(35) Bosch, C.; Andersson, A.; Krusa, M.; Bandh, C.; Hovorkova, I.; Klanova, J.; Knowles, T. D. J.; Pancost, R. D.; Evershed, R. P.; Gustafsson, Ö. Source apportionment of polycyclic aromatic hydrocarbons in central European soils with compound-specific triple isotopes $\left(\delta^{13} \mathrm{C}, \Delta^{14} \mathrm{C}, \delta^{2} \mathrm{H}\right)$. Environ. Sci. Technol. 2015, 49, 76577665.

(36) Cory, R. M.; Ward, C. P.; Crump, B. C.; Kling, G. W. Sunlight controls water column processing of carbon in arctic fresh waters. Science 2014, 345, 925-928.

(37) Ghosal, D.; Ghosh, S.; Dutta, T. K.; Ahn, Y. Current state of knowledge in microbial degradation of polycyclic aromatic hydrocarbons (PAHs): a review. Front. Microbiol. 2016, 7, 1369.

(38) Dombrowski, N.; Donaho, J. A.; Gutierrez, T.; Seitz, K. W.; Teske, A. P.; Baker, B. J. Reconstructing metabolic pathways of hydrocarbon-degrading bacteria from the Deepwater Horizon oil spill. Nature microbial. 2016, 1, 1-7. 